\title{
Comparative Overview of the Mechanisms of Action of Hormones and Endocrine Disruptor Compounds
}

\author{
Yves Combarnous ${ }^{1, *(1)}$ and Thi Mong Diep Nguyen ${ }^{1,2}$ \\ 1 CNRS, INRA, Physiologie de la Reproduction \& des Comportements, 37380 Nouzilly, France; \\ nguyenthimongdiep@qnu.edu.vn \\ 2 Faculty of Biology-Agricultural Engineering, Quy Nhon University, Binh Dinh 820000, Vietnam \\ * Correspondence: yves.combarnous@inra.fr
}

Received: 10 January 2019; Accepted: 22 January 2019; Published: 24 January 2019

\begin{abstract}
Endocrine Disruptor Compounds (EDCs) are synthetic or natural molecules in the environment that promote adverse modifications of endogenous hormone regulation in humans and/or in wildlife animals. In the present paper, we review the potential mechanisms of EDCs and point out the similarities and differences between EDCs and hormones. There was only one mechanism, out of nine identified, in which EDCs acted like hormones (i.e., binding and stimulated hormone receptor activity). In the other eight identified mechanisms of action, EDCs exerted their effects either by affecting endogenous hormone concentration, or its availability, or by modifying hormone receptor turn over. This overview is intended to classify the various EDC mechanisms of action in order to better appreciate when in vitro tests would be valid to assess their risks towards humans and wildlife.
\end{abstract}

Keywords: endocrine disruptor; hormone; receptor; mechanism; risk assessment

\section{Introduction}

Endocrine disruptor compounds (EDCs) are mostly synthetic molecules from industrial origin [1-3] but are also some natural molecules [4,5] that are present in the environment and promote adverse modifications of endocrine homeostasis in humans and/or in wildlife animals. EDCs raise serious concerns about their potential health impact.

Most of the receptors that are targeted by EDCs are nuclear receptors. These receptors are hormone-dependent transcription factors and, consequently, they exert long-term control of their target cells' phenotype. Membrane receptor signaling can also be affected by EDCs but this potentially leads to a short-term effect, since their signaling pathways exert more acute effects in target cells. An interesting case is that of estradiol, that binds to a transmembrane receptor named GPER (or GPR30) in addition to its nuclear receptors ER $\alpha$ and ER $\beta$ [6]. Interestingly, the EDC bisphenol-A exhibits a higher affinity towards GPER than toward its nuclear ER receptors [7].

The understanding of EDCs' mechanisms of action, as well as the extent to which their effects are responsible for health disorders, are the subject of scientific and public controversy. We present here information concerning EDCs compared to hormones in order to evaluate their particular properties and to estimate their potential risks for human and animal health.

In a previous article [8], we summarized the main mechanisms of action of EDCs. We present here a more precise view of the different mechanisms that EDCs can exhibit, including:

(1) Binding to a hormone receptor leading to activation of its signaling pathway;

(2) Binding to a hormone receptor leading to inhibition of its signaling pathway;

(3) Interactions with components of hormone signaling pathway downstream of a receptor; 
(4) Stimulation or

(5) Inhibition of an endogenous hormone biosynthesis;

(6) Binding to circulating hormone-binding protein;

(7) Stimulation or inhibition of hormone-binding protein synthesis or degradation;

(8) Stimulation or

(9) Inhibition of hormone receptor expression.

Among these mechanisms, only the first one is common within the mechanisms of any action relating to hormones. The other mechanisms (numbers 2 to 9) lead to imbalances in endocrine homeostasis that are not consecutive to a direct hormonal-type mechanism of action by EDCs. We have thus taken these various mechanisms into consideration and summarized them in Figure 1, to differentiate the different types of EDCs according to their similarities or differences compared to hormones.
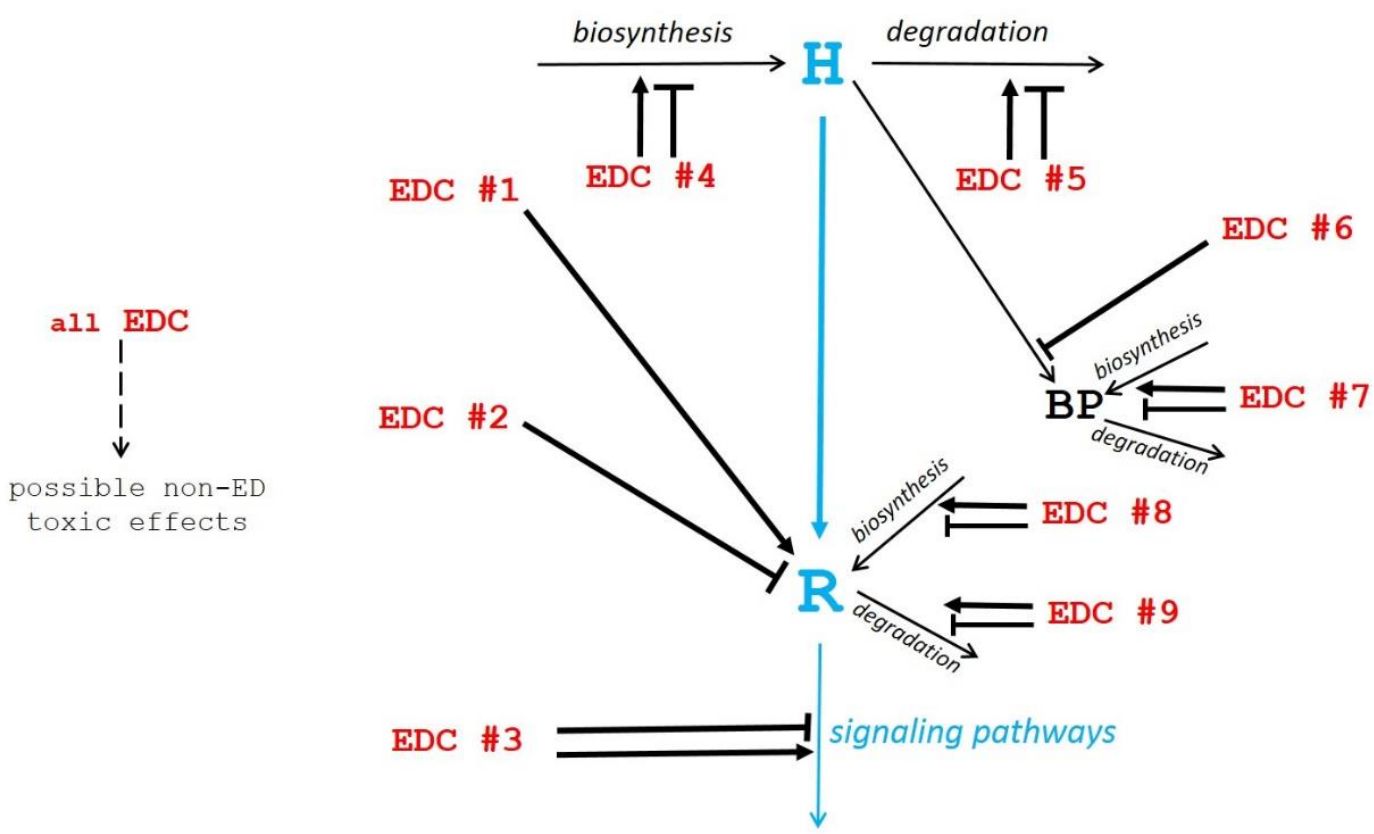

Figure 1. Schematic view of potential mechanisms of action of endocrine disruptor compounds (EDCs). The physiological hormonal mechanism is shown in blue. The diverse EDC mechanisms of action (EDC \#1 to EDC \#9 in red) as described in the text, are shown by black arrows pointing to their site of action $(\rightarrow$ stimulation; -1 inhibition).

\section{EDCs Directly Exhibiting Hormonal Activity Through Receptor Binding (Mechanism 1)}

The most obvious EDCs are those exhibiting a hormone-type mechanism of action, i.e., those able to bind to and activate a hormone receptor (mechanism number 1 above). How is that possible, since hormones are considered to exhibit high affinity and high specificity towards their cognate receptor? Because EDCs exhibiting structures that are different from those of hormones, can sneak into their binding site and interfere with their mechanism of action.

The present hormone receptor (HR) couples, in all today's living species, are the fruit of evolution. Natural selection during evolution does not work on each HR couple individually (and neither on interactions involving each enzyme, structural protein or others) but on organisms exhibiting all possible sets of protein forms and thus, various capabilities to thrive in various environmental situations. Concerning HR couples, it is not sufficient that they exhibit high affinity but also that they do not interfere with others. It must thus have a high specificity so that hormones with almost similar structures (androgens vs. estrogens for example) do not interfere. Thus, evolution has not only selected individual efficient HR couples but also couples without mutual interferences, i.e., receptors 
that recognize their cognate ligand but also inhibit the binding of other molecules with very near structures. Only functional isolation of HR couples allows harmonious endocrine controls.

The massive introduction, in terms of number and quantity, of synthetic molecules having more or less the shape and size of hormones explains that some of them can lure the receptors and bind to them [9]. Indeed, receptors have evolved to recognize their cognate ligand but also to impede the binding of other endogenous molecules with near structures. The receptors are thus protected against interaction with endogenous molecules resembling hormones. However, they cannot be protected against interaction with brand new molecules never encountered before during evolution. In addition, these new synthetic molecules can be present in rather high quantities, and therefore can compete with genuine hormones in spite of their lower affinity towards receptors, compared to hormones.

Examples of this mechanism concern essentially xenobiotics interacting with hormone nuclear receptors. Indeed, these receptors have hormone-binding sites of rather small size that can potentially accommodate many synthetic organic molecules of industrial origin, but also natural molecules. Moreover, as these receptors exhibit transcriptional activity, their activation by xenobiotics can profoundly affect target cells phenotype. Some EDCs nevertheless interact with membrane receptors [10].

There are many examples of this straightforward classical mechanism, in which EDCs act like hormones by direct interaction and activation hormone receptors. Nevertheless, EDCs might be less efficiently degraded than the natural hormones and thus be more active in vivo because of a longer half-life in blood or in cells.

\section{EDCs Directly Inhibiting Endogenous Hormone Action Through Receptor Occupation (Mechanism 2)}

Among the new molecules resembling hormones and able to bind to receptors, some can freeze the receptors conformation in their inactive state, and thus antagonize endogenous hormone action (mechanism number 2 above). Through such a mechanism, exogenous molecules can clearly exert endocrine disruption. For example, polychlorinated biphenyls (PCBs) can suppress transcription through inhibiting the binding of T3 to the thyroid hormone receptor (TR) and consequently, by dissociating the transcriptionally active $\mathrm{TR} /$ retinoid $\mathrm{X}$ receptor heterodimer complex from the thyroid response element (TRE) [11]. Additionally, anti-estrogenic, anti-androgenic, anti-progesteronic, and anti-ER activities were detected in samples from wastewater treatment plants [12].

In this mechanism, EDCs are able to bind to receptors like hormones by exerting an antagonistic effect, in contrast to hormones. This mechanism of action can be tested in vitro but the cytotoxic effects of unknown substances can confound in vitro assays. This can make the interpretation of results difficult and uncertain, particularly when assessing antagonistic activity [13].

\section{EDCs Interacting with Hormone Signaling Pathways (Mechanism 3)}

A number of EDCs interplay with endocrine regulations through direct interaction. This means interaction is not with hormone receptors, but with hormone signaling pathway components downstream of receptor activation. Such molecules can exhibit structures that are largely different from those of hormones.

For example, fluoxetine (FLX) that is the SSRI (selective serotonin reuptake inhibitor) active substance in the Prozac ${ }^{\mathrm{TM}}$ antidepressant has been shown to modify a number of intracellular signaling pathways in various cell types [14-16]. Several bisphenols have been shown to interact with Ras small $\mathrm{G}$ proteins (particularly K-Ras4B) leading to the activation of the Ras signaling cascade, as shown by raised pERK and pAKT levels [17].

Atrazine, one of the most commonly used herbicides worldwide, acts as an endocrine disruptor by inhibiting cAMP-specific phosphodiesterase PDE4 [18] and thus, favors cAMP intracellular accumulation. Tolylfluanid impairs insulin signaling in human adipocytes through a reduction in insulin receptor substrate-1 (IRS-1) levels downstream from the insulin receptor [19]. 
The plasticizer di-(2-ethylhexyl)-phthalate (DEHP) is classified as an endocrine disruptor but also as an obesogen and has been shown to act through the peroxisome proliferator activated receptors (PPARs) [20], provoking downstream effects on AMPK, ERK1, ERK2 and ACC activation through phosphorylation. DEHP can also exhibit non-endocrine reprotoxic effects by directly affecting these pathways in gametes [21].

Recently, neonicotinoid pesticides have been shown to induce a change in CYP19 (aromatase) promoter usage in Hs578t breast cancer cells, leading to increased aromatase catalytic activity and the activation of MAPK 1/3 and/or PLC pathways [22]. This promoter usage change is similar to that observed in patients with hormone-dependent breast cancer. Another example concerns the effect of triclosan, a broad-spectrum antibacterial and antifungal compound, on ovarian [23] and testicular steroidogenesis through miRNAs which are involved in endocrine regulation and disease development in humans [24]. For example, the miR-6321/Map3k1-regulated JNK/c-Jun/Nur77 cascade contributes to a triclosan endocrine disrupting effect [25].

Histone methylation events are a general component of nuclear receptor mediated transcriptional regulation, for example in the testis [26]. DNA methylation of a Wnt2 promoter, under bisphenol-A (BPA) exposure, is implicated in preeclampsia-like effects in mice [27]. BPA also affects cell proliferation of human placental first trimester trophoblasts [28] and is thus of concern for the sensitive window that is fetal development.

In this mechanism, EDCs do not interfere with hormone receptors but downstream of them, at numerous possible sites which can be difficult to identify. Potentially, this type of mechanism should be detectable and quantitated in vitro in cell culture systems. It must be kept in mind that this mechanism can lead to direct, non-endocrine, and toxic effects (Figure 1).

\section{EDCs Affecting Endogenous Hormone Concentration (Mechanisms 4 and 5)}

Many molecules can exert endocrine disruption, not by interfering directly with hormone receptors, but by affecting, positively or negatively, endogenous hormone(s) biosynthesis (mechanism 4) or degradation (mechanism 5). Such molecules generally exhibit structures that are different from those of hormones, since they do not compete with hormones at the receptor level.

\subsection{Mechanism 4}

One example of this mechanism is that of BPA which, at a low dose, inhibits adiponectin secretion in vitro in human adipocytes [29-32]. It has been shown that EDC 4-nonyphenol (4-NP) inhibits the secretion of testosterone by Leydig cells stimulated by human chorionic gonadotropin [33] and triclosan induces Vascular Endothelial Growth Factor (VEGF) secretion by human prostate cancer cells [34].

\subsection{Mechanism 5}

Flame retardants such as polybrominated diphenyl ethers (PBDEs) have been described to act through the induction of hepatic enzymes involved in glucuronidation [11], thus potentially leading to an increase in T4 elimination and the lowering of its concentration in blood. Parabens, which are effective preservatives widely used in cosmetic products, inhibit $17 \beta$-hydroxysteroid dehydrogenase (17 $\beta$-HSD) and consequently inhibit estrogen degradation [35], potentially leading to an increased hormone concentration in blood.

In this mechanism again, EDCs do not interfere with hormone receptors but, by affecting endogenous hormone concentration, impact either their biosynthesis or degradation. Such a mechanism has to be studied in vivo but can be tested in vitro when a specific step has been identified. 


\section{EDCs Affecting Endogenous Free Active Hormone Concentration (Mechanisms 6 and 7)}

Many hormones, particularly the hydrophobic ones (steroids and thyroid hormones), are transported by binding proteins in blood. Since EDCs are generally hydrophobic, they are susceptible to compete with small hydrophobic hormones in relation to these transport proteins.

\subsection{Mechanism 6}

A number of EDCs directly interfere with hormone-binding transport proteins, thus competing with the endogenous hormones' concentration in blood. For example, numerous chemicals have been shown to interact with SHBG (steroid hormone-binding protein) or AFP ( $\alpha$-fetoprotein) [36,37] and thus, able to interfere with steroid hormones transport and concentration in blood. The EDCs exerting their effect through this mechanism exhibit some structural resemblance with the hormones, so that they can compete with them for binding with hormone-binding transport proteins.

In this mechanism, EDCs do not compete with hormones at the receptor level, but at the level of their circulating binding proteins. They can thus exhibit structural resemblance with the hormones they compete with, and this competition can be studied in vitro.

\subsection{Mechanism 7}

Other EDCs affect the biosynthesis or degradation of hormone-binding transport proteins, so that both the total hormone concentration and/or its free active fraction can be affected. The EDCs acting this way can exhibit chemical structures very different from those of hormones. For example, PBDEs act through the down-regulation of the transport protein transthyretin (TTR) [11] and therefore can lower T4 concentration in blood.

Through this mechanism, many toxicants can be catalogued as EDCs because hormone-binding transport proteins are often synthesized and/or degraded by the liver, which, as a (degrading) organ, is the main target of toxicants.

\section{EDCs Affecting Endogenous Hormone Receptor Turn-Over (Mechanisms 8 and 9)}

\subsection{Mechanism 8}

Stimulation of endogenous hormone receptors is a way by which a number of EDCs interfere with endocrine homeostasis. BPA has been shown to stimulate leptin receptor expression in ovarian cancer cells in vitro [31]. Cadmium exposure of endothelial HUVEC cells in vitro induced a significant increase of estradiol receptor $\beta(E R \beta)$ and Cyp19a1 enzymes at both mRNA and protein levels, while a drastic dose-dependent decrease of androgen receptor (AR) expression levels was observed after $24 \mathrm{~h}$ of exposure [38].

\subsection{Mechanism 9}

Inhibition of receptor expression is also a mechanism responsible for EDC alteration of the endocrine system. It has also been described that a low oral dose of BPA given to rats can inhibit estrogen receptor expression in their hypothalamic cells [39]. Likewise, inhibition of androgen receptor expressions by BPA has been described in vivo [29] and in vitro in cells from breast or prostate cancer patients [40]. Such an inhibition has also been observed in newborn rats exposed to BPA and was attributed to hypermethylation of the androgen receptor promoter [41]. Moreover, BPA can selectively affect the expression of the ecdysone receptor gene expression in insects [42], whereas it promotes a decrease in ER $\alpha, E R \beta$ and GPR30 in fetal mammary gland [43].

In these mechanisms, EDCs generally do not need to resemble hormones to exert their adverse effect by modifying receptor availability. Nevertheless, receptor synthesis and/or degradation are often controlled by its cognate hormone [43]. In this case, EDC structural similarity with hormones 
can be responsible for this effect. These mechanisms can potentially be identified and studied in vitro, using cell culture assays.

\section{In Vitro Tests vs. In Vivo Tests}

Mechanisms 1 and 2 are relatively easily amendable to in vitro tests to replace in vivo tests, making use of living animals [44-46]. Mechanisms 8 and 9 can also be potentially studied in vitro. In vivo tests in aquatic animals reproducing EDC concentrations recorded in polluted places in the environment are particularly useful $[47,48]$, but not always easy to interpolate to terrestrial species, including humans.

The limited capabilities of in vitro models to metabolically activate or inactivate xenobiotics may lead to misinterpretation of the in vitro data if such information is missing [49]. These authors have shown that HC11 cells did not show any biotransformation capability, while the major biotransformation pathways in HepG2 and MCF7 cells were conjugated to sulfate and, to a lesser extent, glucuronic acid. These results suggest that HC11 cells should be a valuable cellular system to study the intrinsic estrogenic activity of the tested compound. In these cells, it is thus the concentrations of EDCs in active form that must be taken into consideration. Using HepG2 and MCF7 cells that are able to metabolize activity can help to take into account part of the metabolic fate of the tested compound that occur in vivo.

Since a number of metabolizing enzymes are poorly or not at all expressed in standard in vitro systems, their use in endocrine disruptor testing may result in false negatives for compounds in which bioactivation is a prerequisite.

In vitro and in vivo tests are complementary but in vivo tests have to be kept at a minimum for ethical reasons, providing, nevertheless, that in vitro tests give sufficient reliable information.

\section{Endocrine Disruption vs. Other Toxicological Mechanisms}

Molecules with recognized endocrine disruption activity can also have additional adverse effects through other toxicological mechanisms. They can directly be cytotoxic or reprotoxic (i.e., direct alteration of gametogenesis or other reproductive steps) [50], or teratogenic or genotoxic (alteration of DNA: either by epigenetic alterations or through mutations), possibly leading to cancers independent of endocrine-related cancers. For example, BPA exhibits cytotoxic and genotoxic effects not related to its EDC properties [50-52]. Likewise, dioxin that acts as an EDC through the aryl hydrocarbon receptor (AhR) [53] has also been shown to be a potent genotoxic [54]. Although these cytotoxic and genotoxic effects are generally observed at higher concentrations than endocrine-disturbing effects, this possibility must be taken into consideration.

As with the other toxicants, EDCs exhibit longer effects during early developmental steps, such as embryonic, fetal, neonatal, childhood, and puberty periods [52,55]. Obviously, defects during developmental steps will have consequences during the whole life of the exposed individual [56] and sometimes in its descendants, as these effects often occur through epigenetic mechanisms [57]. Whatever the mechanism in action, it would be wise to study EDC effects in these sensitive windows and observe the consequences in adults. Nevertheless, numerous and long-term experiments for testing individual EDCs or mixtures in animals would be nearly impossible for all suspected molecules. It is therefore advantageous to classify individual molecules according to their disturbing mechanisms, in order to get a better analysis of their synergies in mixtures.

\section{EDCs Mechanisms of Action and Risk Assessment}

As stated in the WHO-UNEP 2012 document [58], EDCs represent a challenge as their effects depend on both the level and timing of exposure, being especially critical when exposure occurs during development. "Risk assessment" is the term generally used to refer to the characterization of the potential adverse effects of exposure to hazards. The evaluation of EDC risk assessment is an issue leading to controversies [58-61]. 
Therefore, the timing of exposure and of its acceptable quantitative limits are of major interest to assess risk [62]. Nevertheless, the existence of dose-thresholds for endocrine disruptors continues to be debated [63-67] because non-monotonous dose response (NMDR) curves are often considered as an intrinsic property of EDCs in the non-scientific press and general public. It is rather a property derived from the complexity of endocrine regulations [64]. It remains nevertheless, that it can be difficult to distinguish a valid true threshold from an apparent threshold, which merely arises from the limits of detection of the experimental system used.

If a molecule exhibits a U-shape dose-response curve in a given experimental system, the $\mathrm{U}$ descending branch of the curve should be used as the basis for determining the threshold if the registered response is related to the adverse effect of the molecule. This can lead to exceedingly low limits but, at least, this is more satisfying than, by principle, refusing any limit. Of course, the determination of the control value in the total absence of the molecule under test is primordial to demonstrate a significative, positive or negative, effect at these very low doses.

Author Contributions: Both authors, Y.C. and T.M.D.N., carried out the writing and editing of this Review.

Funding: This research received no external funding.

Conflicts of Interest: The authors declare no conflict of interest.

\section{References}

1. Westerhoff, P.; Yoon, Y.; Snyder, S.; Wert, E. Fate of endocrine-disruptor, pharmaceutical, and personal care product chemicals during simulated drinking water treatment processes. Environ. Sci. Technol. 2005, 39, 6649-6663. [CrossRef]

2. Van den Berg, K.J.; van Raaij, J.A.; Bragt, P.C.; Notten, W.R. Interactions of halogenated industrial chemicals with transthyretin and effects on thyroid hormone levels in vivo. Arch. Toxicol. 1991, 65, 15-19. [CrossRef]

3. Zoeller, R.T. Environmental chemicals as thyroid hormone analogues: New studies indicate that thyroid hormone receptors are targets of industrial chemicals? Mol. Cell. Endocrinol. 2005, 242, 10-15. [CrossRef]

4. Lecomte, S.; Demay, F.; Ferriere, F.; Pakdel, F. Phytochemicals Targeting Estrogen Receptors: Beneficial Rather Than Adverse Effects? Int. J. Mol. Sci. 2017, 18, 1381. [CrossRef]

5. Wynne-Edwards, K.E. Evolutionary biology of plant defenses against herbivory and their predictive implications for endocrine disruptor susceptibility in vertebrates. Environ. Health. Perspect. 2001, 109, 443-448. [CrossRef]

6. Pakdel, F. Molecular Pathways of Estrogen Receptor Action. Int. J. Mol. Sci. 2018, 19, 2591. [CrossRef]

7. Kerdivel, G.; Habauzit, D.; Pakdel, F. Assessment and molecular actions of endocrine-disrupting chemicals that interfere with estrogen receptor pathways. Int. J. Endocrinol. 2013, 2013, 501851. [CrossRef]

8. Combarnous, Y. Endocrine Disruptor Compounds (EDCs) and agriculture: The case of pesticides. C. R. Biol. 2017, 340, 406-409. [CrossRef]

9. Montes-Grajales, D.; Olivero-Verbel, J. EDCs DataBank: 3D-Structure database of endocrine disrupting chemicals. Toxicology 2015, 327, 87-94. [CrossRef]

10. Sheng, Z.; Wang, C.; Ren, F.; Liu, Y.; Zhu, B. Molecular mechanism of endocrine-disruptive effects induced by Bisphenol A: The role of transmembrane G-protein estrogen receptor 1 and integrin alphavbeta3. J. Environ. Sci. (China) 2019, 75, 1-13. [CrossRef]

11. Boas, M.; Feldt-Rasmussen, U.; Main, K.M. Thyroid effects of endocrine disrupting chemicals. Mol. Cell. Endocrinol. 2012, 355, 240-248. [CrossRef]

12. Rao, K.; Li, N.; Ma, M.; Wang, Z. In vitro agonistic and antagonistic endocrine disrupting effects of organic extracts from waste water of different treatment processes. Front. Environ. Sci. Eng. Chin. 2014, 8, 69-78. [CrossRef]

13. Marin-Kuan, M.; Fussell, K.C.; Riederer, N.; Latado, H.; Serrant, P.; Mollergues, J.; Coulet, M.; Schilter, B. Differentiating true androgen receptor inhibition from cytotoxicity-mediated reduction of reporter-gene transactivation in-vitro. Toxicol. in Vitro 2017, 45, 359-365. [CrossRef] 
14. Stepulak, A.; Rzeski, W.; Sifringer, M.; Brocke, K.; Gratopp, A.; Kupisz, K.; Turski, L.; Ikonomidou, C. Fluoxetine inhibits the extracellular signal regulated kinase pathway and suppresses growth of cancer cells. Cancer Biol. Ther. 2008, 7, 1685-1693. [CrossRef]

15. Liu, X.L.; Luo, L.; Mu, R.H.; Liu, B.B.; Geng, D.; Liu, Q.; Yi, L.T. Fluoxetine regulates mTOR signalling in a region-dependent manner in depression-like mice. Sci. Rep. 2015, 5, 16024. [CrossRef]

16. Ofek, K.; Schoknecht, K.; Melamed-Book, N.; Heinemann, U.; Friedman, A.; Soreq, H. Fluoxetine induces vasodilatation of cerebral arterioles by co-modulating NO/muscarinic signalling. J. Cell. Mol. Med. 2012, 16, 2736-2744. [CrossRef]

17. Schopel, M.; Shkura, O.; Seidel, J.; Kock, K.; Zhong, X.; Loffek, S.; Helfrich, I.; Bachmann, H.S.; Scherkenbeck, J.; Herrmann, C.; et al. Allosteric Activation of GDP-Bound Ras Isoforms by Bisphenol Derivative Plasticisers. Int. J. Mol. Sci. 2018, 19, 1133. [CrossRef]

18. Kucka, M.; Pogrmic-Majkic, K.; Fa, S.; Stojilkovic, S.S.; Kovacevic, R. Atrazine acts as an endocrine disrupter by inhibiting cAMP-specific phosphodiesterase-4. Toxicol. Appl. Pharmacol. 2012, 265, 19-26. [CrossRef]

19. Sargis, R.M.; Neel, B.A.; Brock, C.O.; Lin, Y.; Hickey, A.T.; Carlton, D.A.; Brady, M.J. The novel endocrine disruptor tolylfluanid impairs insulin signaling in primary rodent and human adipocytes through a reduction in insulin receptor substrate-1 levels. Biochim. Biophys. Acta 2012, 1822, 952-960. [CrossRef]

20. Schaedlich, K.; Gebauer, S.; Hunger, L.; Beier, L.S.; Koch, H.M.; Wabitsch, M.; Fischer, B.; Ernst, J. DEHP deregulates adipokine levels and impairs fatty acid storage in human SGBS-adipocytes. Sci. Rep. 2018, 8, 3447. [CrossRef]

21. Nguyen, T.M. Impact of 5'-amp-activated Protein Kinase on Male Gonad and Spermatozoa Functions. Front. Cell. Dev. Biol. 2017, 5, 25. [CrossRef] [PubMed]

22. Caron-Beaudoin, E.; Viau, R.; Sanderson, J.T. Effects of Neonicotinoid Pesticides on Promoter-Specific Aromatase (CYP19) Expression in Hs578t Breast Cancer Cells and the Role of the VEGF Pathway. Environ. Health Perspect. 2018, 126, 047014. [CrossRef]

23. Chen, W.; Yang, X.; Wang, B.; Wang, L.; Yu, X. The effects and possible mechanisms of triclosan on steroidogenesis in primary rat granulosa cells. Reprod. Toxicol. 2018, 83, 28-37. [CrossRef] [PubMed]

24. Cameron, B.E.; Craig, P.M.; Trudeau, V.L. Implication of microRNA deregulation in the response of vertebrates to endocrine disrupting chemicals. Environ. Toxicol. Chem. 2016, 35, 788-793. [CrossRef] [PubMed]

25. Ha, M.; Zhang, P.; Li, L.; Liu, C. Triclosan Suppresses Testicular Steroidogenesis via the miR-6321/JNK/ Nur77 Cascade. Cell. Physiol. Biochem. 2018, 50, 2029-2045. [CrossRef]

26. Anderson, A.M.; Carter, K.W.; Anderson, D.; Wise, M.J. Coexpression of nuclear receptors and histone methylation modifying genes in the testis: Implications for endocrine disruptor modes of action. PLOS ONE 2012, 7, e34158. [CrossRef] [PubMed]

27. Ye, Y.; Tang, Y.; Xiong, Y.; Feng, L.; Li, X. Bisphenol A exposure alters placentation and causes preeclampsia-like features in pregnant mice involved in reprogramming of DNA methylation of WNT2. FASEB J. 2018. [CrossRef] [PubMed]

28. Basak, S.; Srinivas, V.; Duttaroy, A.K. Bisphenol-A impairs cellular function and alters DNA methylation of stress pathway genes in first trimester trophoblast cells. Reprod. Toxicol. 2018, 82, 72-79. [CrossRef] [PubMed]

29. Qiu, L.-L.; Wang, X.; Zhang, X.-h.; Zhang, Z.; Gu, J.; Liu, L.; Wang, Y.; Wang, X.; Wang, S.-L. Decreased androgen receptor expression may contribute to spermatogenesis failure in rats exposed to low concentration of bisphenol A. Toxicol. Lett. 2013, 219, 116-124. [CrossRef]

30. Fenichel, P.; Chevalier, N.; Brucker-Davis, F. Bisphenol A: An endocrine and metabolic disruptor. Ann. Endocrinol. (Paris) 2013, 74, 211-220. [CrossRef]

31. Ptak, A.; Gregoraszczuk, E.L. Bisphenol A induces leptin receptor expression, creating more binding sites for leptin, and activates the JAK/Stat, MAPK/ERK and PI3K/Akt signalling pathways in human ovarian cancer cell. Toxicol. Lett. 2012, 210, 332-337. [CrossRef]

32. Hugo, E.R.; Brandebourg, T.D.; Woo, J.G.; Loftus, J.; Alexander, J.W.; Ben-Jonathan, N. Bisphenol A at environmentally relevant doses inhibits adiponectin release from human adipose tissue explants and adipocytes. Environ. Health Perspect. 2008, 116, 1642-1647. [CrossRef] [PubMed] 
33. Jambor, T.; Tvrda, E.; Tusimova, E.; Kovacik, A.; Bistakova, J.; Forgacs, Z.; Lukac, N. In vitro effect of 4-nonylphenol on human chorionic gonadotropin (hCG) stimulated hormone secretion, cell viability and reactive oxygen species generation in mice Leydig cells. Environ. Pollut. 2017, 222, 219-225. [CrossRef] [PubMed]

34. Derouiche, S.; Mariot, P.; Warnier, M.; Vancauwenberghe, E.; Bidaux, G.; Gosset, P.; Mauroy, B.; Bonnal, J.L.; Slomianny, C.; Delcourt, P.; et al. Activation of TRPA1 Channel by Antibacterial Agent Triclosan Induces VEGF Secretion in Human Prostate Cancer Stromal Cells. Cancer Prev. Res. (Phila) 2017, 10, 177-187. [CrossRef] [PubMed]

35. Engeli, R.T.; Rohrer, S.R.; Vuorinen, A.; Herdlinger, S.; Kaserer, T.; Leugger, S.; Schuster, D.; Odermatt, A. Interference of Paraben Compounds with Estrogen Metabolism by Inhibition of 17beta-Hydroxysteroid Dehydrogenases. Int. J. Mol. Sci. 2017, 18, 2007. [CrossRef] [PubMed]

36. Sheikh, I.A.; Turki, R.F.; Abuzenadah, A.M.; Damanhouri, G.A.; Beg, M.A. Endocrine Disruption: Computational Perspectives on Human Sex Hormone-Binding Globulin and Phthalate Plasticizers. PLoS ONE 2016, 11, e0151444. [CrossRef] [PubMed]

37. Hong, H.; Branham, W.S.; Ng, H.W.; Moland, C.L.; Dial, S.L.; Fang, H.; Perkins, R.; Sheehan, D.; Tong, W. Human sex hormone-binding globulin binding affinities of 125 structurally diverse chemicals and comparison with their binding to androgen receptor, estrogen receptor, and alpha-fetoprotein. Toxicol. Sci. 2015, 143, 333-348. [CrossRef] [PubMed]

38. Fittipaldi, S.; Bimonte, V.M.; Soricelli, A.; Aversa, A.; Lenzi, A.; Greco, E.A.; Migliaccio, S. Cadmium exposure alters steroid receptors and proinflammatory cytokine levels in endothelial cells in vitro: A potential mechanism of endocrine disruptor atherogenic effect. J. Endocrinol. Invest. 2018.

39. Rebuli, M.E.; Cao, J.; Sluzas, E.; Delclos, K.B.; Camacho, L.; Lewis, S.M.; Vanlandingham, M.M.; Patisaul, H.B. Investigation of the Effects of Subchronic Low Dose Oral Exposure to Bisphenol A (BPA) and Ethinyl Estradiol (EE) on Estrogen Receptor Expression in the Juvenile and Adult Female Rat Hypothalamus. Toxicol. Sci. 2014, 140, 190-203. [CrossRef]

40. Stossi, F.; Dandekar, R.D.; Bolt, M.J.; Newberg, J.Y.; Mancini, M.G.; Kaushik, A.K.; Putluri, V.; Sreekumar, A.; Mancini, M.A. High throughput microscopy identifies bisphenol AP, a bisphenol A analog, as a novel AR down-regulator. Oncotarget 2016, 7, 16962-16974. [CrossRef]

41. Doshi, T.; Mehta, S.S.; Dighe, V.; Balasinor, N.; Vanage, G. Hypermethylation of estrogen receptor promoter region in adult testis of rats exposed neonatally to bisphenol A. Toxicology 2011, 289, 74-82. [CrossRef]

42. Planello, R.; Martinez-Guitarte, J.L.; Morcillo, G. The endocrine disruptor bisphenol A increases the expression of HSP70 and ecdysone receptor genes in the aquatic larvae of Chironomus riparius. Chemosphere 2008, 71, 1870-1876. [CrossRef] [PubMed]

43. Wadia, P.R.; Cabaton, N.J.; Borrero, M.D.; Rubin, B.S.; Sonnenschein, C.; Shioda, T.; Soto, A.M. Low-dose BPA exposure alters the mesenchymal and epithelial transcriptomes of the mouse fetal mammary gland. PLOS ONE 2013, 8, e63902. [CrossRef]

44. Bishop, P.L.; Willett, C.E. The use and acceptance of Other Scientifically Relevant Information (OSRI) in the U.S. Environmental Protection Agency (EPA) Endocrine Disruptor Screening Program. Birth Defects Res. B Dev. Reprod. Toxicol. 2014, 101, 3-22. [CrossRef] [PubMed]

45. Kim, T.S.; Yoon, C.Y.; Jung, K.K.; Kim, S.S.; Kang, I.H.; Baek, J.H.; Jo, M.S.; Kim, H.S.; Kang, T.S. In vitro study of Organization for Economic Co-operation and Development (OECD) endocrine disruptor screening and testing methods - establishment of a recombinant rat androgen receptor (rrAR) binding assay. J. Toxicol. Sci. 2010, 35, 239-243. [CrossRef]

46. Juberg, D.R.; Borghoff, S.J.; Becker, R.A.; Casey, W.; Hartung, T.; Holsapple, M.P.; Marty, M.S.; Mihaich, E.M.; Van Der Kraak, G.; Wade, M.G.; et al. t4 workshop report-lessons learned, challenges, and opportunities: The U.S. Endocrine Disruptor Screening Program. ALTEX 2014, 31, 63-78.

47. Mennigen, J.A.; Stroud, P.; Zamora, J.M.; Moon, T.W.; Trudeau, V.L. Pharmaceuticals as neuroendocrine disruptors: Lessons learned from fish on Prozac. J. Toxicol. Environ. Health B Crit. Rev. 2011, 14, 387-412. [CrossRef] [PubMed]

48. Mennigen, J.A.; Zamora, J.M.; Chang, J.P.; Trudeau, V.L. Endocrine disrupting effects of waterborne fluoxetine exposure on the reproductive axis of female goldfish, Carassius auratus. Comp. Biochem. Physiol. C Toxicol. Pharmacol. 2017, 202, 70-78. [CrossRef] 
49. Bursztyka, J.; Perdu, E.; Pettersson, K.; Pongratz, I.; Fernandez-Cabrera, M.; Olea, N.; Debrauwer, L.; Zalko, D.; Cravedi, J.P. Biotransformation of genistein and bisphenol A in cell lines used for screening endocrine disruptors. Toxicol. In Vitro 2008, 22, 1595-1604. [CrossRef]

50. Horan, T.S.; Pulcastro, H.; Lawson, C.; Gerona, R.; Martin, S.; Gieske, M.C.; Sartain, C.V.; Hunt, P.A. Replacement Bisphenols Adversely Affect Mouse Gametogenesis with Consequences for Subsequent Generations. Curr. Biol. 2018, 28, 2948-2954. [CrossRef]

51. Huang, F.-M.; Chang, Y.-C.; Lee, S.-S.; Ho, Y.-C.; Yang, M.-L.; Lin, H.-W.; Kuan, Y.-H. Bisphenol A exhibits cytotoxic or genotoxic potential via oxidative stress-associated mitochondrial apoptotic pathway in murine macrophages. Food Chem. Toxicol. 2018, 122, 215-224. [CrossRef]

52. Chen, C.-H.; Jiang, S.S.; Chang, I.S.; Wen, H.-J.; Sun, C.-W.; Wang, S.-L. Association between fetal exposure to phthalate endocrine disruptor and genome-wide DNA methylation at birth. Environ. Res. 2018, 162, 261-270. [CrossRef] [PubMed]

53. Kolluri, S.K.; Jin, U.-H.; Safe, S. Role of the aryl hydrocarbon receptor in carcinogenesis and potential as an anti-cancer drug target. Arch. Toxicol. 2017, 91, 2497-2513. [CrossRef] [PubMed]

54. Nguyen, D.; Nguyen, H.; Nguyen, T.; Nguyen, T.; Nakano, K.; Maejima, K.; Sasaki-Oku, A.; Nguyen, V.; Nguyen, D.; Le, B.; et al. Whole Genome Sequencing of a Vietnamese Family from a Dioxin Contamination Hotspot Reveals Novel Variants in the Son with Undiagnosed Intellectual Disability. Int. J. Environ. Res. Public Health 2018, 15, 2629. [CrossRef]

55. Kundakovic, M.; Gudsnuk, K.; Franks, B.; Madrid, J.; Miller, R.L.; Perera, F.P.; Champagne, F.A. Sex-specific epigenetic disruption and behavioral changes following low-dose in utero bisphenol A exposure. Proc. Natl. Acad. Sci. USA 2013, 110, 9956-9961. [CrossRef] [PubMed]

56. Schönfelder, G.; Flick, B.; Mayr, E.; Talsness, C.; Paul, M.; Chahoud, I. In utero exposure to low doses of bisphenol A lead to long-term deleterious effects in the vagina. Neoplasia 2002, 4, 98-102. [CrossRef] [PubMed]

57. Barouki, R.; Melen, E.; Herceg, Z.; Beckers, J.; Chen, J.; Karagas, M.; Puga, A.; Xia, Y.; Chadwick, L.; Yan, W.; et al. Epigenetics as a mechanism linking developmental exposures to long-term toxicity. Environ. Int. 2018, 114, 77-86. [CrossRef]

58. Bergman, A.; Heindel, J.J.; Jobling, S.; Kidd, K.A.; Zoeller, R.T. State of the Science of Endocrine Disrupting Chemicals 2012 Summary for Decision-Makers; World Health Organization, United Nations Environment Programme (WHO-UNEP): Geneva, Switzerland, 2013.

59. Lamb, J.C.t.; Boffetta, P.; Foster, W.G.; Goodman, J.E.; Hentz, K.L.; Rhomberg, L.R.; Staveley, J.; Swaen, G.; Van Der Kraak, G.; Williams, A.L. Comments on the opinions published by Bergman et al. (2015) on Critical Comments on the WHO-UNEP State of the Science of Endocrine Disrupting Chemicals (Lamb et al., 2014). Regul. Toxicol. Pharmacol. 2015, 73, 754-757. [CrossRef]

60. Bergman, Å.; Becher, G.; Blumberg, B.; Bjerregaard, P.; Bornman, R.; Brandt, I.; Casey, S.C.; Frouin, H.; Giudice, L.C.; Heindel, J.J. Manufacturing doubt about endocrine disrupter science-A rebuttal of industry-sponsored critical comments on the UNEP/WHO report "State of the Science of Endocrine Disrupting Chemicals 2012". Regul. Toxicol. Pharmacol. 2015, 73, 1007-1017. [CrossRef]

61. Lamb, J.C.t.; Boffetta, P.; Foster, W.G.; Goodman, J.E.; Hentz, K.L.; Rhomberg, L.R.; Staveley, J.; Swaen, G.; Van Der Kraak, G.; Williams, A.L. Critical comments on the WHO-UNEP State of the Science of Endocrine Disrupting Chemicals-2012. Regul. Toxicol. Pharmacol. 2014, 69, 22-40. [CrossRef]

62. Dekant, W.; Colnot, T. Endocrine effects of chemicals: Aspects of hazard identification and human health risk assessment. Toxicol. Lett. 2013, 223, 280-286. [CrossRef]

63. Solecki, R.; Kortenkamp, A.; Bergman, A.; Chahoud, I.; Degen, G.H.; Dietrich, D.; Greim, H.; Hakansson, H.; Hass, U.; Husoy, T.; et al. Scientific principles for the identification of endocrine-disrupting chemicals: A consensus statement. Arch. Toxicol. 2017, 91, 1001-1006. [CrossRef] [PubMed]

64. Borgert, C.J.; Baker, S.P.; Matthews, J.C. Potency matters: Thresholds govern endocrine activity. Regul. Toxicol. Pharmacol. 2013, 67, 83-88. [CrossRef] [PubMed]

65. Vandenberg, L.N.; Colborn, T.; Hayes, T.B.; Heindel, J.J.; Jacobs, D.R., Jr.; Lee, D.H.; Shioda, T.; Soto, A.M.; vom Saal, F.S.; Welshons, W.V.; et al. Hormones and endocrine-disrupting chemicals: Low-dose effects and nonmonotonic dose responses. Endocr. Rev. 2012, 33, 378-455. [CrossRef] [PubMed] 
66. Villar-Pazos, S.; Martinez-Pinna, J.; Castellano-Munoz, M.; Alonso-Magdalena, P.; Marroqui, L.; Quesada, I.; Gustafsson, J.A.; Nadal, A. Molecular mechanisms involved in the non-monotonic effect of bisphenol-a on ca2+ entry in mouse pancreatic beta-cells. Sci. Rep. 2017, 7, 11770. [CrossRef] [PubMed]

67. Li, L.; Andersen, M.E.; Heber, S.; Zhang, Q. Non-monotonic dose-response relationship in steroid hormone receptor-mediated gene expression. J. Mol. Endocrinol. 2007, 38, 569-585. [CrossRef] [PubMed] 